\title{
Determination of Informal Sector as Urban Pollution Source : Fume Characterization of Small-scale Manual Metal Arc Welding using Factor Analysis in Bandung City
}

\author{
A. Nastiti ${ }^{1{ }^{*}}$, D.Y. Pramudyastuti ${ }^{1}$, K. Oginawati ${ }^{1}$ and M. Santoso ${ }^{2}$ \\ ${ }^{1}$ Environmental Engineering, Bandung Institute of Technology \\ $\mathrm{Jl}$. Ganesha 10, Bandung 40132, Indonesia \\ ${ }^{2}$ Nuclear Technology Center for Materials and Radiometry, National Nuclear Energy Agency \\ Jl. Tamansari 71, Bandung 40132, Indonesia
}

\section{ARTICLE INFO}

Article history:

Received 5 December 2011

Received in revised form 17 April 2012

Accepted 20 April 2012

Keywords:

Informal welding

Welding fume

Characterization

Factor analysis

\begin{abstract}
A B S T R A C T
In developing countries, the informal sector, particularly small-scale welding activities, are considered to be an important contributor to urban air pollution although studies in this sector are limited. This study aims to identify the composition of small-scale welding fume in order to further investigate the effects and set control strategies and urban pollution abatement policies. Breathing zone air samples were collected from 30 mild steel manual metal arc welders and 17 nonwelders in Bandung City, West Java, Indonesia. The respirable particulates in air samples were analyzed using gravimetric method, and Instrumental Neutron Activation Analysis (INAA) was employed to identify characteristic of welding fume. It was found that respirable particulates concentration in welders (range : 315.6 and $3,735.93 \mu \mathrm{gm}^{-3}$; average $1,545.436 \mu \mathrm{gm}^{-3}$ ) were significantly

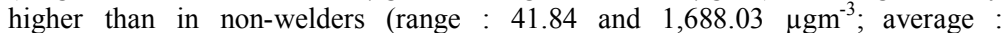
$375.783 \mu \mathrm{gm}^{-3}$ ). Welders' breathing zones contain $\mathrm{Fe}>\mathrm{Na}>\mathrm{K}>\mathrm{Mn}>\mathrm{Al}$ $>\mathrm{Cr}>\mathrm{Ti}>\mathrm{Cl}>\mathrm{Br}>\mathrm{I}>\mathrm{Zn}>\mathrm{Sb}>\mathrm{V}>\mathrm{Co}>\mathrm{Sc}$; while non-welders' breathing zones contain $\mathrm{Cr}>\mathrm{F}>\mathrm{Al}>\mathrm{Ti}>\mathrm{Na}>\mathrm{Br}>\mathrm{I}>\mathrm{Mn}>\mathrm{Cl}>\mathrm{Co}>\mathrm{Zn}>\mathrm{Sc}$. Inter-species correlation analysis conducted using Statgraphic Ver. 4.0 shows that Fe (range : n.d. $-775.19 \mu \mathrm{gm}^{-3}$; average: $0.1674 \mu \mathrm{gm}^{-3}$ ), Co (range : n.d. $-0.51 \mu \mathrm{gm}^{-3}$; average: $0.000082 \mu \mathrm{gm}^{-3}$ ), $\mathrm{Mn}$ (range : $0.39-148.37 \mu \mathrm{gm}^{-3}$; average: $0.0374 \mathrm{\mu gm}^{-3}$ ), $\mathrm{Na}$ (range: 0.17 and $623.85 \mu \mathrm{gm}^{-3}$; average: $0.0973 \mu \mathrm{gm}^{-3}$ ) and $\mathrm{K}$ (range : n.d. $-301.15 \mu \mathrm{gm}^{-3}$; average: $0.0535 \mathrm{\mu gm}^{-3}$ ) were emitted from welding activity, and thus are considered as components of welding fume which contribute to urban air pollution. Although welding fume and the identified species in welding fume were still below permissible limit, small-scale welding activities have great potential in emitting higher fume concentration due to due to high variability of welding activities, such as welding frequency, materials being welded, and varied environmental conditions.
\end{abstract}

\section{INTRODUCTION}

Rapid urbanization and increase of human activities in urban area are known to have strong link with the escalation of urban air pollution. The impacts of human activities are particularly severe in the Asian region [1]. Previous studies show that airborne particulate concentration in Bandung City as the capital city of West Java Province, Indonesia, has increased during 20042005 due to several pollution sources [2], typically from energy production, traffic and from industrial

\footnotetext{
* Corresponding author.

E-mail address: anindrya@gmail.com
}

processes [3]. Compared with in most other places, this problem is more severe in Bandung City, since it is located inside a valley, therefore preventing pollutants' release into the upper atmosphere.

In developing countries, air quality problems are not only generated by aforementioned activities. The informal sector ${ }^{1}$, as an attempt for survival by the urban poors, must be taken into account since

\footnotetext{
${ }^{1}$ The term 'informal sector' has many interpretations. In this case, as defined by the International Labor Organization, it comprises smallscale units consisting of independent, self employed producers, some of whom also employ family labor and/or apprentice; which operate with very little capital; at low level of productivity, providing irregular incomes; unregulated by the government; and generally live and work in appalling, often dangerous and unhealthy condition, even without basic sanitary facilities [4].
} 
several pollution-intensive informal activities, such as tanning, brickmaking, automotive repair, wood finishing, metalworking and electroplating significantly contribute to urban environmental quality $[4,5]$. Although the informal sector provides most of the employment in most developing countries [6], the pollution it causes cannot be overlooked. Generalizations about the environmental impacts of informal sector might be misleading since several types of small-scale business create fewer environmental problems than vehicular emission or other activities [7]. In contrast, municipal government lacks a clear understanding of the magnitude and incidence of the environmental damages of informal sector [8]. Therefore, studies regarding contribution of informal sector to urban environment must be conducted in regard to set place urban pollution abatement policies.

Privately owned small-scale welding activities are generally found in the cities of developing countries. Many of them use electric arc and mild steel as the parent metal, utilizing a technique known as manual metal arc welding (MMAW). Respirable particulate matters emitted from the mild steel MMAW process, containing $\mathrm{F}$, $\mathrm{K}, \mathrm{Ca}, \mathrm{Mn}, \mathrm{Fe}, \mathrm{Zn}$, and $\mathrm{Pb}$ [9], can contribute to urban air pollution and pose various health risks to welders and those who live nearby. Further, this effect is made worse by the high variablity of small-scale welding activities and lack of safety measures and emission control strategies in informal welding sector.

Therefore, it is important to identify the composition of small-scale welding fume in order to further investigate the effects of the fume and to set control strategies. This is even more so since such studies for small-scale activities were hardly ever performed. This paper will discuss the identification and characterization of species contained in smallscale manual metal arc welding fume collected from the breathing zones of welders and non-welders in Bandung City.

\section{EXPERIMENTAL METHODS}

The study was initiated by observing smallscale welding workshops throughout the Bandung area. Large numbers of welding workshops emitting hazardous metals and other compounds are feared to worsen the pollution in Bandung. The accurate data regarding the exact number of welding workshops is still unknown, but in general, welding workshops in Bandung City are quite numerous and geographically distributed, making them difficult to monitor. Furthermore, new welding activities emerge sporadically in real estate project development areas, targeting new residences which probably need fences, awnings, and other metal products for the newly built housings. Jalan Bogor and Cingised were chosen as study locations since welding activities in Bandung City are concentrated in those areas. Both locations are located near residential area and contain several commercial activities. The total numbers of samples and controls suitable for a scientific research are 30-500 samples and 10-20 controls, respectively [10]. Therefore, breathing zone air samples were collected from 30 welders and 17 non-welders as controls. The non-welders work as street shoe merchants in Kosambi, far from welding workshops to avoid welding exposures. All welders are smokers, therefore the controls selected are also smokers to make obtained results comparable.

The observed welding activities utilize manual metal arc welding, in which the parent metal and the electrodes are heated using electrical arc into liquid phase, allowing the molten electrode to bridge the gap between parent metal pieces [11]. The activities are conducted in small open workshops in street sidelines, with one to five welders per workshop which operate from 8.00 a.m. to 16.30 p.m., Monday to Sunday, although the welding intensity greatly depends on customers' order.

The materials being welded are mild steel, which consists mostly of iron, as parent metal, and electrodes containing carbon, silica, selenium, phsophorus, and manganese. The Nikko Steel RD260 and the Atlantic E6013 are electrode brands commonly used by welders in the study areas. They contain $0.5 \% \mathrm{Mn}, 0.08 \%$ $\mathrm{C}, 0.3 \% \mathrm{Si}, 0.02 \% \mathrm{~S}, 0.02 \% \mathrm{P}$; and $0.48 \% \mathrm{Mn}$,

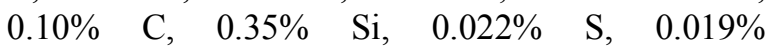
$\mathrm{P}$, respectively.

Welding activities are known to produce fumes which consist of 0.01-2 $\mu \mathrm{m}$ agglomerates of metal oxide nanoparticles formed during high-temperature metalurgical processes [12]. This study was focused on fine particles in welding fume, since respirable particulates are the ones which will enter the lung, stay in alveoli, and cause health problems [13]. Breathing zone air samples were taken using a Hi Flow Personal Sampler Gillian HFS-513A with mixed cellulose estherfilter $(25 \mathrm{~mm}$ in diameter) with a pore size of $0.8 \mu \mathrm{m}$ with SKC aluminium cyclone 225-01-01/02. 
The respirable particulates in air samples were analyzed using gravimetric method [14], and the elemental analysis of welding fume were conducted using Instrumental Neutron Activation Analysis (INAA). INAA has advantages compared with other methods, including its simultaneous measurement, multi-elemental analysis, high sensitivity, short analysis time, and non-destructive properties $[14,15]$. Standard reference materials (SRM) were used to ensure high accuracy of results.

The determination of the sources of the species contained in air sample, to ensure whether the identified component in air samples were generated from the welding activities, was performed using receptor models technique. This technique employs air quality measurements of particle bound chemical species to apportion the contributions of various sources [3]. The main sources of particulate matter are resolved from the sample data measured and analyzed using factor analysis, which has a successful application in source apportionment of particulate matter [15]. Chemical species with similar variabilities are grouped together in a minimum number of factors representing pollution sources, which explain the variability of the data set $[15,16]$. In this study, chemical species grouped within one of the factors are predicted to be the elements of welding fume. The factor analysis was conducted using Statgraphic Ver.4.0, with several iterations of data to obtain factors with strong inter-species correlation.

\section{RESULTS AND DISCUSSION}

Concentration of respirable particulates and metals on welding fume of welders and breathing zone air of non-welders

Based on calculations using gravimetric method, concentration of respirable particulates of non-welders was found to range between 41.84 and $1,688.03 \mu \mathrm{gm}^{-3}$ (average $375.783 \mu \mathrm{gm}^{-3}$ ), while the concentrations of respirable particulates of welders vary between 315.6 and 3,735.93 ${\mu \mathrm{gm}^{-3}}^{-3}$ (average 1,545.436 $\mu^{-3} \mathrm{gm}^{-3}$ ). Figure 1 shows the distribution of respirable particulates in welders and non welder samples, and controls. The average concentration of respirable particulates in the breathing zones of welders was four times as high as in the breathing zones of non-welders.

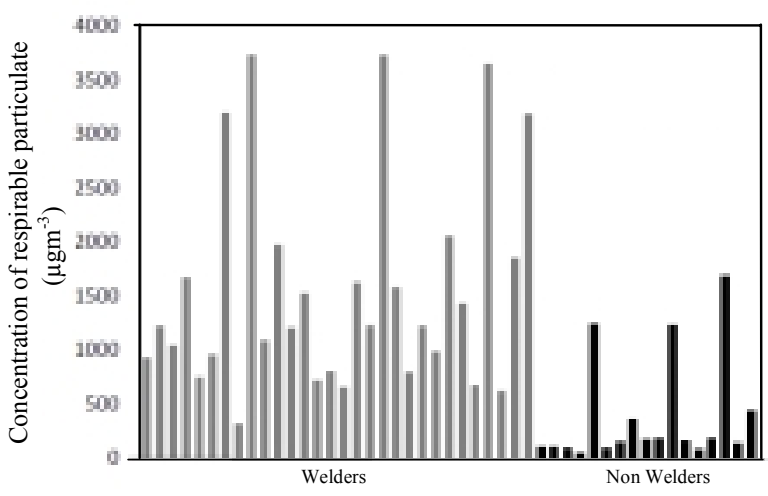

Fig. 1. Concentration of respirable particulates in breathing zone of welders and non welder samples, and controls.

The average concentrations of respirable particulates in commercial area, residential area, conservation area, and industrial area in Bandung City from a previous study were shown in Table 1.

It was found in this study that respirable particulate concentrations, both in location of welders and controls were much higher than found in previous studies. This could be due to various factors.

Table 1. Weekdays respirable particulate concentration in Bandung City [14]

\begin{tabular}{lcc}
\hline \multicolumn{1}{c}{ Location } & $\begin{array}{c}\text { Concentration range } \\
\left(\mu \mathrm{gm}^{-3}\right)\end{array}$ & $\begin{array}{c}\text { Average } \\
\text { concentration } \\
\left(\mu \mathrm{gm}^{-3}\right)\end{array}$ \\
\hline Commercial area & $48.97-107.72$ & 83.28 \\
Residential area & $22.58-157.13$ & 67.93 \\
Conservation area & $21.30-61.73$ & 51.30 \\
Industrial area & $26.85-104.63$ & 72.65 \\
\hline
\end{tabular}

First, all participants in this study are smokers. It is known that cigarette smoke is a strong factor which affect personal exposure for $\mathrm{PM}_{2.5}$, where active smokers have respirable particulate exposure as much as three times as non-smokers, and passive smokers have twice as much as non-smokers [3,14]. Second, the sampling locations are in the streetside. The locations of both welding and non-welding activities serve as commercial area and are located in streetside line, and are frequently passed by numerous motor vehicles emitting particulate matters. Identified respirable particulate concentration for welders in this study were 18 times higher than respirable particulate in commercial area on previous study. It is clear that welding activities highly affect concentration of respirable particulate in air. 
The working hours of welders on sampling day varied between 6 to 8 hours. The conversion of respirable particulate concentrations resulted in Time Weighted Average (TWA) value 1,665.874 ${\mu \mathrm{gm}^{-3}}^{-3}$ The Threshold Limit Value Time Weighted Average (TLV-TWA) of welding fume recommended by ACGIH is $5000 \mu^{-3}$. Although respirable particulates concentrations in welders were still below its maximum allowable concentration, the health hazard cannot be left unattended, considering the high variability of welding activities. In addition, both study areas are located near residential areas, so exposure risk of welding fume components may occur to neighboring residents.

Figure 2 shows the differences of concentration distributions of welders and non-welders, while Table 2 shows the ranges of concentrations of welding fume and breathing zone air of non-welders. High variation were found in concentrations of each chemical species obtained in welders' breathing zones since samples were taken from wideranging volume of welding activities. Chemical species in upper left graph of Fig. 2 have the highest concentrations among them, with iron (Fe) as the highest. Welders breathing zones contain the following chemical species, from highest concentration to the lowest one; $\mathrm{Fe}, \mathrm{Na}, \mathrm{K}, \mathrm{Mn}, \mathrm{Al}, \mathrm{Cr}, \mathrm{Ti}, \mathrm{Cl}, \mathrm{Br}, \mathrm{I}, \mathrm{Zn}$, $\mathrm{Sb}, \mathrm{V}, \mathrm{Co}$, Sc. Meanwhile, non-welders' breathing zones contain $\mathrm{Cr}$ with the highest concentration, followed by $\mathrm{Fe}, \mathrm{Al}, \mathrm{Ti}, \mathrm{Na}, \mathrm{Br}, \mathrm{I}, \mathrm{Mn}, \mathrm{Cl}, \mathrm{Co}$, $\mathrm{Zn}$, and Sc. Meanwhile, K, V, and Sb were not detected in samples of breathing zone air of non-welders. $\mathrm{Mg}, \mathrm{Cu}, \mathrm{Ca}$, and $\mathrm{La}$ were excluded from Table 2 since they were not detected both in welders and non welders breathing zones. It was shown that average concentration of $\mathrm{Mn}$, $\mathrm{Cl}, \mathrm{Zn}, \mathrm{Na}$, and $\mathrm{Fe}$ breathed by welders were 50,22 , 12,10 , and 8 times higher than detected in non welders, respectively. $\mathrm{Cl}$ detected in welders' breathing zones in this study was much lower than previous study [14]. Moreover, $\mathrm{K}$ was detected in relatively high concentration in welders' breathing zones but was not detected in breathed air samples of non-welders. Although cobalt is not stated in labels of electrodes used in study area, it was detected in welders' breathing zones. Cobalt was probably come from minor elements of electrodes which were not stated in the label, from other electrode brands, or from other pollution sources.
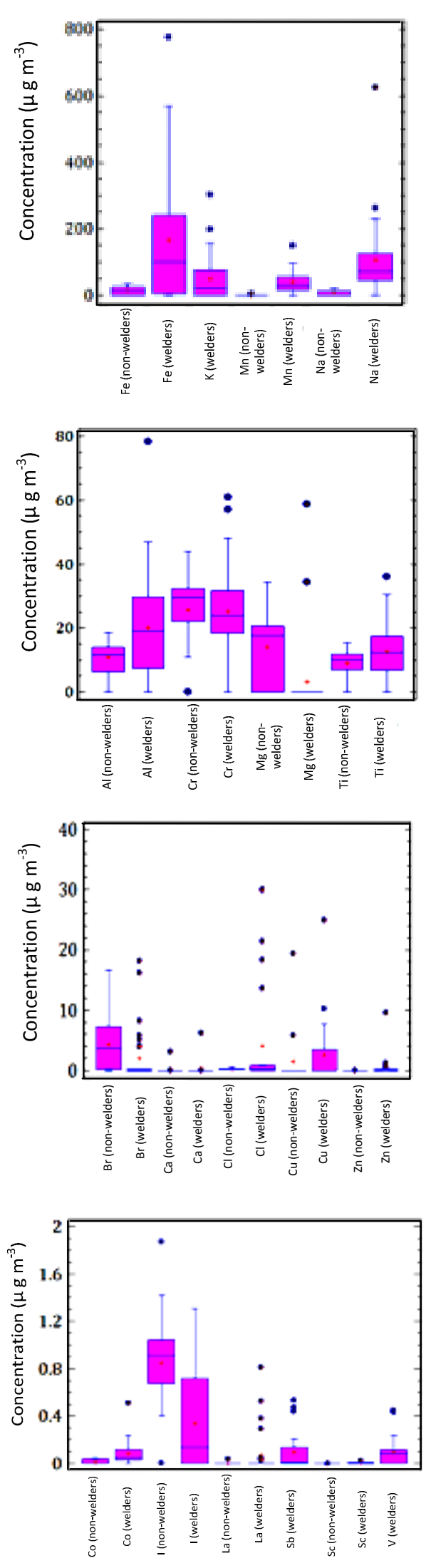

Fig. 2. Chemical species concentration found in welders and non-welders. 
Table 2. Concentration range of breathing zone samples of welders (welding fume) and non-welders

\begin{tabular}{|c|c|c|c|c|c|}
\hline \multirow[b]{2}{*}{$\begin{array}{l}\text { Chemical } \\
\text { species }\end{array}$} & \multicolumn{2}{|c|}{ Welders } & \multicolumn{2}{|c|}{ Non Welders } & \multirow[b]{2}{*}{$\begin{array}{c}\text { Average } \\
\text { Concen- } \\
\text { tration in } \\
\text { previous } \\
\text { study } \\
\left(\mu \mathrm{gm}^{-3}\right)\end{array}$} \\
\hline & $\begin{array}{c}\text { Concentration } \\
\text { range } \\
\left(\mu \mathrm{gm}^{-3}\right)\end{array}$ & $\begin{array}{c}\text { Average } \\
\text { concen- } \\
\text { tration } \\
\left(\mu \mathrm{gm}^{-3}\right)\end{array}$ & $\begin{array}{c}\text { Concentration } \\
\text { range } \\
\left(\mu \mathrm{gm}^{-3}\right)\end{array}$ & $\begin{array}{c}\text { Average } \\
\text { concen- } \\
\text { tration } \\
\left(\mu \mathrm{gm}^{-3}\right)\end{array}$ & \\
\hline $\mathrm{Fe}$ & n.d.- 775.19 & 0.1674 & n.d. -34.04 & 0.0198 & - \\
\hline $\mathrm{K}$ & n.d. -301.15 & 0.0535 & n.d. & n.d. & - \\
\hline $\mathrm{Mn}$ & $0.39-148.37$ & 0.0374 & $0.194-6.1$ & 0.00074 & $0.024^{*}$ \\
\hline $\mathrm{Na}$ & $0.17-623.85$ & 0.0973 & n.d. -21.55 & 0.0094 & $0.002 *$ \\
\hline Al & n.d. -337.15 & 0.0319 & n.d. -18.56 & 0.0115 & $1.118^{*}$ \\
\hline $\mathrm{Cr}$ & n.d. -60.99 & 0.0234 & n.d. -43.91 & 0.0291 & - \\
\hline $\mathrm{Ti}$ & n.d. -36.03 & 0.0137 & n.d. -15.38 & 0.0096 & n.d \\
\hline $\mathrm{Br}$ & n.d. -16.18 & 0.0029 & n.d. -16.69 & 0.0046 & $0.101^{*}$ \\
\hline $\mathrm{Cl}$ & n.d. -43.29 & 0.0051 & $0.071-0.5$ & 0.00023 & $2.706^{*}$ \\
\hline $\mathrm{Zn}$ & n.d. -9.62 & 0.000196 & n.d. -0.05 & 0.000016 & - \\
\hline Co & n.d. -0.51 & 0.000082 & n.d. -0.049 & 0.000038 & - \\
\hline I & n.d. -1.31 & 0.00061 & n.d. -1.87 & 0.00096 & $0.014^{*}$ \\
\hline $\mathrm{Sb}$ & n.d. -0.54 & 0.000153 & n.d. & n.d. & - \\
\hline $\mathrm{Sc}$ & n.d. -0.021 & 0.0000038 & n.d. -0.002 & 0.00000157 & - \\
\hline $\mathrm{V}$ & n.d. -0.45 & 0.00013 & n.d. & n.d. & $0.004^{*}$ \\
\hline
\end{tabular}

Subsequently, Al, Sc, Co, and Ti were found in higher concentrations in welders than in non-welders, but the difference in concentrations between welders and non-welders is less marked than is the case with $\mathrm{Mn}, \mathrm{Cl}, \mathrm{Zn}, \mathrm{Na}$, and $\mathrm{Fe}$. Further, $\mathrm{V}$ and $\mathrm{Sb}$ were found in small concentration in welders and not detected in non welders. Meanwhile, concentrations of $\mathrm{Cr}$, I and $\mathrm{Br}$ in non-welders were higher than those detected in welders.

In general, the concentrations of primary species detected in high concentration were still below Threshold Limit Value. However, the highest concentration of manganese $(\mathrm{Mn})$ in detected welders was $148.37 \mu \mathrm{gm}^{-3}$, close to its TLV-TWA $\left(200 \mu^{-3}\right)^{-3}$ recommended by ACGIH. This finding must be taken into account in exposure control of welding fumes, since a previous study found that mean concentrations of airborne, blood, and urinary manganese in welders were significantly higher than controls [17]. Manganese is recognized as causing adverse health effect, mainly metal fume fever and a central nervous system disorder called "manganism" [18].

\section{Identification of pollution source using correlation analysis and factor analysis}

The total species found in samples of welders and non-welders suggest that several pollution sources might be present. In general, a pollution source contains specific chemical species with inter-species strong correlation. In identification process of a pollution source, dominant species in a pollution source play important role as determining elements. The correlation coefficient (r) is used in identification of pollution source by selecting species with positive correlation coefficient valued more that 0.6 [9]. A correlation coefficient (r) of $0.6-0.799$ indicates a strong inter-species correlation, while positive value of $r$ is selected to see the increase of a species compared with other species [9]. By following those considerations, inter-species correlation analysis were conducted to species in welding fume samples of welders, breathing zone air samples of non-welders, and between samples of welders and non welders, using Statgraphic Ver. 4.0. Table 3 and Table 4 shows the correlation results.

Table 3. Inter-species correlation with $r$ values $\geq 0.6$

\begin{tabular}{lll}
\hline $\begin{array}{r}\text { Inter-species correlation in } \\
\text { welding fume samples of } \\
\text { welders }\end{array}$ & $\begin{array}{c}\text { Inter-species correlation in } \\
\text { breathing zone air samples } \\
\text { of non-welders }\end{array}$ \\
\hline $\mathrm{Al}$ with $\mathrm{Cu}$ & $\mathrm{Fe}$ with $\mathrm{Sb}$ & $\mathrm{Al}$ with $\mathrm{Co}$ \\
$\mathrm{Al}$ with $\mathrm{Mg}$ & $\mathrm{Fe}$ with $\mathrm{Sc}$ & Al with I \\
$\mathrm{Cu}$ with $\mathrm{Mg}$ & $\mathrm{K}$ with $\mathrm{Mn}$ & $\mathrm{Al}$ with $\mathrm{Mg}$ \\
$\mathrm{Cl}$ with $\mathrm{Sc}$ & $\mathrm{K}$ with $\mathrm{Na}$ & $\mathrm{Cl}$ with Co \\
$\mathrm{Co}$ with $\mathrm{Fe}$ & $\mathrm{Mn}$ with $\mathrm{Na}$ & $\mathrm{Cr}$ with I \\
$\mathrm{Co}$ with $\mathrm{Mn}$ & $\mathrm{Mn}$ with $\mathrm{Sb}$ & $\mathrm{Cr}$ with $\mathrm{Ti}$ \\
$\mathrm{Fe}$ with $\mathrm{Mn}$ & $\mathrm{Na}$ with $\mathrm{Sb}$ & $\mathrm{Cu}$ with $\mathrm{Zn}$ \\
$\mathrm{Fe}$ with $\mathrm{Na}$ & $\mathrm{Sb}$ with $\mathrm{Sc}$ & \\
\hline
\end{tabular}

The results show that strong correlation between $\mathrm{Fe}$ and other species were only found in welding fume samples. It was therefore concluded that $\mathrm{Fe}$ is emitted by welding activity as specific source. In order to support the idea, correlation between $\mathrm{Fe}, \mathrm{Mn}$ and $\mathrm{Na}$ were plotted as demonstrated in Fig. 3 below.

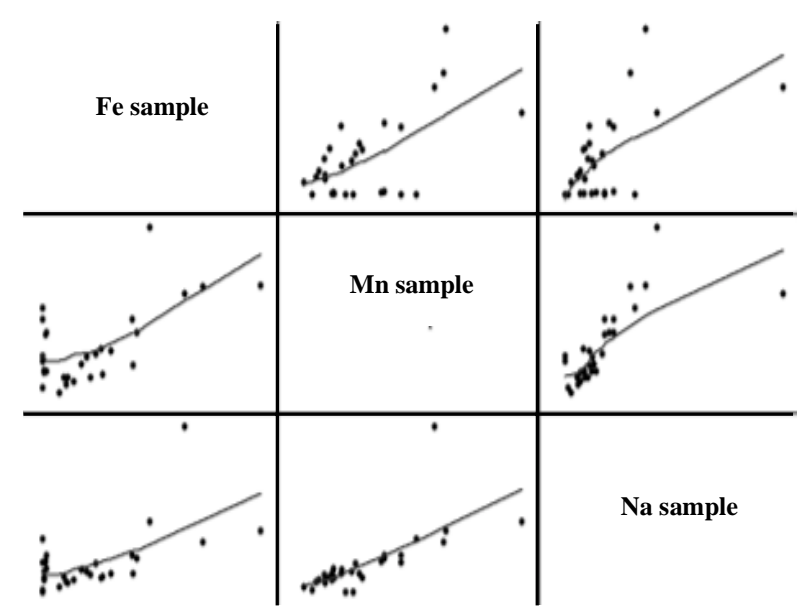

Fig. 3. Correlation of $\mathrm{Fe}, \mathrm{Mn}$, and $\mathrm{Na}$ in welding fume samples. 


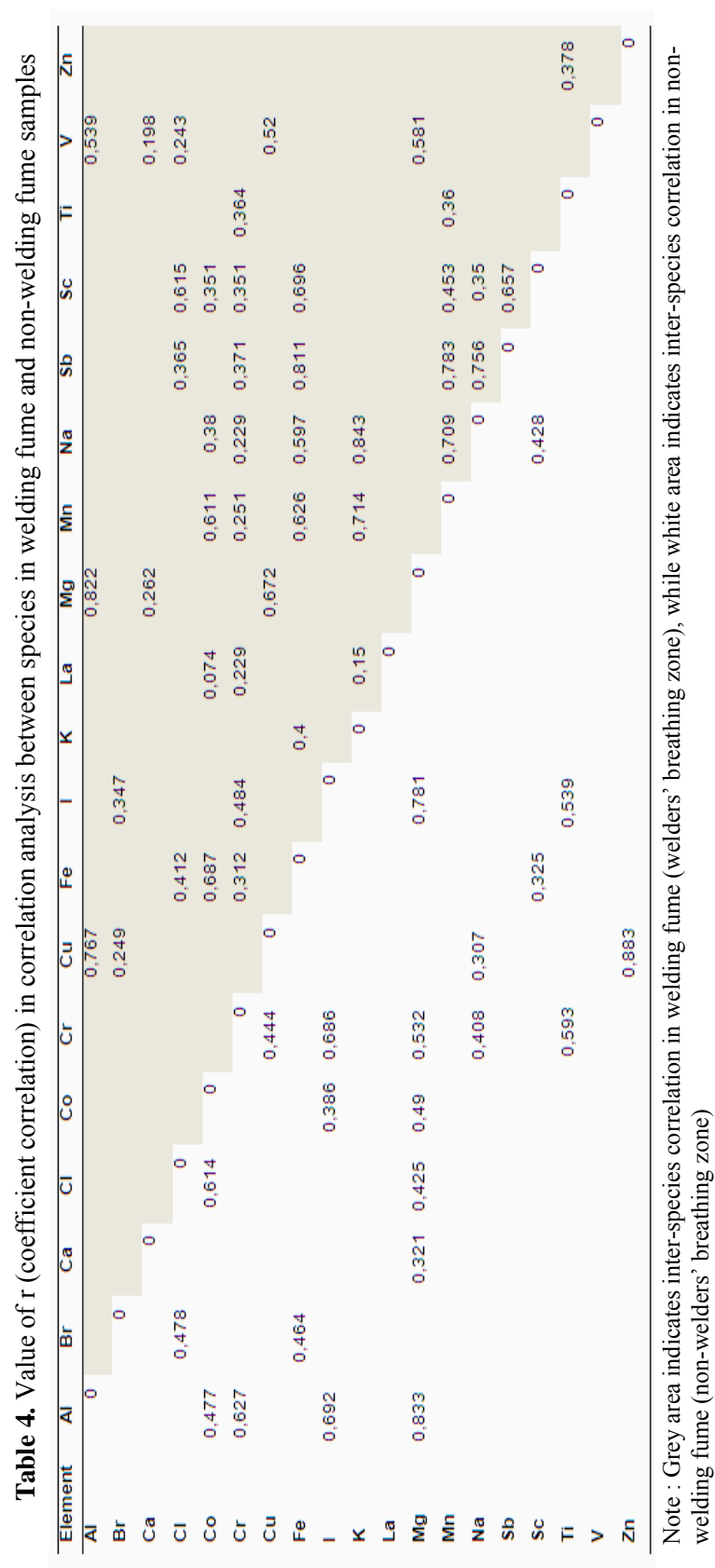

The correlation coefficients between Fe with $\mathrm{Co}, \mathrm{Mn}, \mathrm{Na}, \mathrm{Sb}$ and $\mathrm{Sc}$ are shown in Table 5 below. It is clear that the correlations of $\mathrm{Fe}$ with $\mathrm{Mn}, \mathrm{Na}$, $\mathrm{Co}, \mathrm{Sb}$ and $\mathrm{Sc}$ in air samples of welders were stronger than in non-welders, which were mostly low, even negative. In addition, $\mathrm{K}$ is found to have strong correlations with $\mathrm{Mn}$ and $\mathrm{Na}$. This indicates that $\mathrm{Fe}, \mathrm{Mn}, \mathrm{Na}, \mathrm{K}, \mathrm{Co}, \mathrm{Sb}$ and $\mathrm{Sc}$ are emitted from welding activity. Moreover, strong correlations were found between $\mathrm{Al}, \mathrm{Cu}$ dan $\mathrm{Mg}$ in air samples of welders. A strong correlation between $\mathrm{Al}$ and $\mathrm{Mg}$ were also found in air samples of non-welders, indicating other possible sources of pollution in study area. Additionally, factor analysis was conducted to determine whether Fe, Co, Mn, Na, $\mathrm{Sb}$, and $\mathrm{Sc}$ are components of welding fumes.

Table 5. Correlation coefficients of $\mathrm{Fe}, \mathrm{Mn}, \mathrm{Na}, \mathrm{Co}, \mathrm{Sb}$ dan $\mathrm{Sc}$

\begin{tabular}{lcc}
\hline & \multicolumn{2}{c}{ Correlation coefficient (r) } \\
\cline { 2 - 3 } \multicolumn{1}{c}{ Inter-species } & Welders & Non-welders \\
& & \\
\hline Fe with Mn & 0.626 & -0.122 \\
Fe with Na & 0.597 & -0.171 \\
Fe with Co & 0.687 & 0.187 \\
Fe with Sb & 0.811 & - \\
Fe with Sc & 0.696 & 0.325 \\
Mn with Na & 0.709 & -0.234 \\
Mn with Co & 0.611 & -0.143 \\
Mn with Sb & 0.783 & - \\
Sb with Sc & 0.657 & - \\
\hline
\end{tabular}

Factor analysis is conducted by reducing a number of variables into more meaningful variables. Several iterations using Statgraphic Ver 4.0 resulted in maximum reduction of 19 welding fume elements into 16 elements, with the eigenvalue of 1.3 . Elements in welding fume were grouped into 4 factors to obtain optimum result. From each factor, pollution sources that contribute to the elements in welding fume can be determined by knowing the strength of dominant elements in welding fume. The strength of dominant elements is expressed by factor loading value as shown in Table 6 below.

Table 6. Matrix of factor loading values of welding fume in welders

\begin{tabular}{ccccc}
\hline & Factor 1 & Factor 2 & Factor 3 & Factor 4 \\
\hline $\mathrm{Al}$ & - & 0.5374 & 0.1665 & \\
$\mathrm{Br}$ & - & 0.1655 & - & 0.1507 \\
$\mathrm{Ca}$ & - & - & 0.8395 & \\
$\mathrm{Cl}$ & - & - & - & \\
$\mathrm{Co}$ & 0.6914 & 0.3757 & & \\
$\mathrm{Cr}$ & - & 0.7713 & & 0.26 \\
$\mathrm{Fe}$ & 0.7646 & - & & \\
$\mathrm{K}$ & 0.5513 & - & 0.2025 & \\
$\mathrm{La}$ & 0.1706 & 0.5128 & & \\
$\mathrm{Mg}$ & - & - & 0.7765 & \\
$\mathrm{Mn}$ & 0.6007 & 0.5791 & 0.816 & \\
$\mathrm{Na}$ & 0.6722 & - & & \\
$\mathrm{Sb}$ & - & 0.8620 & & \\
$\mathrm{Ti}$ & - & 0.2689 & 0.4524 & 0.3166 \\
$\mathrm{~V}$ & - & - & 0.2635 & 0.5985 \\
$\mathrm{Zn}$ & 0.2419 & - & & \\
\hline
\end{tabular}


The dominant species in Factor 1 were Co, $\mathrm{Fe}, \mathrm{K}, \mathrm{Mn}$ and $\mathrm{Na}$. The result is similar with correlation analysis results which identified $\mathrm{Fe}, \mathrm{K}$, $\mathrm{Co}, \mathrm{Mn}, \mathrm{Na}, \mathrm{K}, \mathrm{Sb}$ and $\mathrm{Sc}$, as welding fume elements. It is concluded that Factor 1 contains elements emitted from welding activity, which were $\mathrm{Fe}, \mathrm{Co}, \mathrm{Mn}, \mathrm{Na}$ dan $\mathrm{K}$; this results agrees with a previous study that stated $\mathrm{Fe}, \mathrm{Mn}, \mathrm{Si}, \mathrm{K}$, $\mathrm{Ca}$, and $\mathrm{Na}$ as welding fume components [13]. However, $\mathrm{Ca}$ was not detected both in welders and non-welders in this study and method employed in this study is still not able to measure Si concentration.

Pollution source of Factor 2, Factor 3, and Factor 4 were indicated to result from soil, construction, and motor vehicles, respectively. Al, $\mathrm{Mn}$ and $\mathrm{Ti}$ indicate soil dust as pollution source; $\mathrm{Ca}$ is characterized as cement element; and $\mathrm{Zn}$ is produced from motor vehicle emission [16]. The presence of species in Factor 2, 3, and 4 shows that welding fume composition was contributed by other pollution source. Soil and motor vehicle emission were assumed to come from road activity while cement from construction activities near study location.

Table 7 presents the percentages of $\mathrm{Fe}$ and Mn concentration to welding fume, compared with the reference [9]. Percentages of $\mathrm{Fe}, \mathrm{Mn}$, and $\mathrm{K}$ concentration are quite comparable with reference value, pointing that $\mathrm{Fe}, \mathrm{Co}, \mathrm{Mn}, \mathrm{Na}$, and $\mathrm{K}$ are welding fume components.

Table 7. Comparison of percentage of element concentrations in welding fume with reference value

\begin{tabular}{ccc}
\hline Elements & Reference (\%) [9] & Sample (\%) \\
\hline $\mathrm{Fe}$ & $11-32$ & n.d. -20.75 \\
$\mathrm{Co}$ & - & n.d. -0.01 \\
$\mathrm{Mn}$ & $2.8-5.9$ & $0.12-3.97$ \\
$\mathrm{Na}$ & - & $0.05-16.7$ \\
$\mathrm{~K}$ & $9-19$ & n.d. -8.06 \\
\hline
\end{tabular}

Similar factor analyses conducted on breathing zone air samples of non-welders resulted that Factor 1, 2, 3, and 4 were dominated by elements that indicating soil dust (Al); motor vehicle emission $(\mathrm{Br})$ and sea salt evaporation $(\mathrm{Cl})$; industrial pollution $(\mathrm{Cu})$; and motor vehicle emission $(\mathrm{Br})$, respectively. This result is similar to that of a previous study, where it was found that atmospheric pollution sources in Bandung City are soil dust, motor vehicle, biomass incineration, sea salt, and road dust [15].

\section{Recommendation}

Further investigations are required to analyze Si and F species, which are known to be welding fume component. Also, since particular health hazards linked to the welding fume in welders and general population have not been studied, research regarding exposure of welding fume and each species containing in it can be conducted using the result of this study. It is recommended that more comprehensive and upscaled studies are carried out in order to obtain quantitative contribution of welding activities to overall pollution in Bandung, to assess the effects of seasonal variation on welding emission, and link to health impacts caused by this activity.

Welding activities must be equipped with adequate facilities in order to comply with safety standards and reduce emission. Nevertheless, law enforcement approach is seemingly ineffective to overcome this problem with informal welding sectors, partly because most of the welding workshops do not have business establishment permit. In addition, government regulation and monitoring of informal sectors is insufficient, in this case in Bandung City and West Java Province. The comprehensive study regarding source identification and risk assessment can be used in set up policies regarding pollution caused by informal sectors. Several policy options can be reviewed to enhance the participation of the informal sector in urban pollution abatement.

\section{CONCLUSION}

Identified components of small-scale manual metal arc welding fume in this study are $\mathrm{Fe}$, Co, $\mathrm{Mn}, \mathrm{Na}$, and $\mathrm{K}$, with higher concentration detected in welders than non-welders. Welding activities contribute to increase of these species in urban air environment. Although welding fume and the identified species in welding fume were still below permissible limit, small-scale welding activities have great potential in emitting higher fume concentration due to due to high variability of welding activities, such as welding frequency, materials being welded, and varied environmental conditions.

\section{ACKNOWLEDGEMENT}

This study is partly funded by the Center of Nuclear Technology for Materials and Radiometry (BATAN). 


\section{REFERENCES}

1. P.K. Hopke, et al., Sci. Total Environ. 404 (2008) 103.

2. M. Santoso, H. Achmad and DL. Diah, Characterization of airborne particulate matter in Bandung and Lembang sites using instrumental neutron activation analysis, Proceedings of the Environmental Technology and Management Conference (2006).

3. K. Koistinen, Exposure of an urban adult population to $\mathrm{PM}_{2.5}$, methods, determination, and sources, Ph.D. Thesis, Finland (2002).

4. A.F. Montalvo, Commercial and informal atmospheric emissions in the Mexico City Metropolitan Area : scenario analysis and policy proposals, Master's Thesis, Massachusset Institute of Technology (2003).

5. A. Blackman and G.J. Bannister, Pollution Control in the Informal Sector in: the Ciudad Juárez Brickmakers' Project, Discussion Paper 98-15, Resources for the Future, Washington D.C. (1998).

6. S. Chaudhuri, Pollution and welfare in the presence of informal sector: is there any trade-off?, Department of Economics, University of Calcutta, India (2005).

7. A. Blackman, Informal Sector Pollution Control : What Policy Option Do We Have?, Resources for the Future, Washington D.C. (1999).

8. A. Blackman, S. Newbold, J. Shih and J. Cook, The Benefits and Costs of Informal Sector Pollution Control: Mexican Brick Kilns, Resources for the Future, Washington D.C. (2000).
9. Anonymous, International Agency for Research on Cancer (IARC), Chromium, Nickel and Welding Fumes, IARC Monographs on the Evaluation of Carcinogenic Risks to Humans (1990) 49.

10. Sugiyono, Statistika Untuk Penelitian, CV Alfabeta, Bandung (2008).

11. Anonymous, National Occupational Health and Safety Commission, Welding: Fumes And Gases, Australian Government Publishing Service, Canberra (1990).

12. N.T. Jenkins, S. Adelman, and R.W. Eagar, Aerosol Sci. Technol. 29 (2005) 170.

13. J. Soemirat, et al., Toksikologi Lingkungan, Gadjah Mada University Press, Yogyakarta, (2003) 80 .

14. N. Zannaria, Chemical Characteristic Study of Respirable Particulate Exposure, Master's, Thesis, Institut Teknologi Bandung (2008).

15. M. Santoso, P.K. Hopke, A. Hidayat and D. Dwiana, Sci. Total Environ. 397 (2008) 229.

16. W. Chueinta, P.K. Hopke and P. Paatrob, Atmos. Environ. 34 Issue 20 (2000) 3319.

17. A. Nastiti, K. Oginawati and M. Santoso, Journal of Applied Sciences in Environmental Sanitation V N (2010) 215.

18. Anonymous, Agency fo Toxic Substances and Disease Registry, Draft : Toxicological Profile for Manganese, U.S. Department of Health and Human Services, Public Health Service, Atlanta, (1999). 